\title{
Glucose metabolic abnormality is associated with defective mineral homeostasis in skeletal disorder mouse model
}

\author{
ZOU JiangHuan, XIONG XiWen, LAI BeiBei, SUN Min, TU Xin \& GAO Xiang* \\ MOE Key Laboratory of Model Animal for Disease Study, Model Animal Research Center, Nanjing University, Nanjing 210061, China
}

Received August 3, 2014; accepted December 31, 2014

\begin{abstract}
Bone was reported as a crucial organ for regulating glucose homeostasis. In this study, we found that Phex mutant mice (PUG), a model of human X-linked hypophosphatemic rickets (XLH), displayed metabolic abnormality in addition to abnormal phosphate homeostasis, skeletal deformity and growth retardation. Glucose tolerance was elevated with enhanced insulin sensitivity in PUG, though circulating insulin level decreased. Interestingly, bone mineral density defects and glucose metabolic abnormality were both rescued by adding phosphorus- and calcium-enriched supplements in daily diet. Serum insulin level, glucose tolerance and insulin sensitivity showed no differences between PUG and wild-type mice with rescued osteocalcin (OCN) following treatment. Our study suggested that OCN is a potential mediator between mineral homeostasis and glucose metabolism. This investigation brings a new perspective on glucose metabolism regulation through skeleton triggered mineral homeostasis and provides new clues in clinical therapeutics of potential metabolic disorders in XLH patients.
\end{abstract}

glucose metabolism, mineral homeostasis, bone, Phex, X-linked hypophosphatemic rickets

Citation: Zou JH, Xiong XW, Lai BB, Sun M, Tu X, Gao X. Glucose metabolic abnormality is associated with defective mineral homeostasis in skeletal disorder mouse model. Sci China Life Sci, 2015, 58: 359-367, doi: 10.1007/s11427-015-4827-2

$\mathrm{X}$-linked hypophosphatemic rickets (XLH), also known as $\mathrm{X}$-linked vitamin D-resistant rickets, is one of the rachitic bone diseases with an incidence rate of about 1 in 20,000 [1]. Patients with XLH usually show rickets in children and osteomalacia in adults. XLH is characterized by growth retardation, impaired phosphate reabsorption, affected bone mineralization, low level of $1,25-(\mathrm{OH})_{2} \mathrm{D}_{3}$ and occasionally dental abscess [2,3]. Most XLH patients possess various mutations on gene Phex $[3,4]$, abbreviated for phosphate regulating gene with homologies to endopeptidases on the $\mathrm{X}$ chromosome, proving the importance of PHEX functions in skeletal morphology and mineral homeostasis $[5,6]$.

In the past decades, bone was studied as an endocrinal organ $[7,8]$. Interactions between bone and energy metabolism aroused extensive interests and concerns [9-11]. Phex

*Corresponding author (email: gaoxiang@nju.edu.cn) is mainly expressed in osteoblasts and odontoblasts [12-14] and its mutations lead to reduced $1,25-(\mathrm{OH})_{2} \mathrm{D}_{3}$ and elevated circulating FGF23 (fibroblast growth factor 23) [15-17]. $1,25-(\mathrm{OH})_{2} \mathrm{D}_{3}$ and its receptor could influence expression of uncoupling protein (UCP) in adipocytes $[18,19]$. In vitro studies demonstrate that the role of $1,25-(\mathrm{OH})_{2} \mathrm{D}_{3}$ in lipid metabolism is regulator of peroxisome proliferator-activated receptor alpha (Ppara) [20]. Circulating FGF23 is also associated with fat mass and serum lipids [21]. In mouse models of XLH, like Hyp mice, decreased renal glucose reabsorption activity [22], increased glucose production in renal proximal tubules [23] and osteoblasts [24] were observed. The only known physiological substrate of PHEX protein, acidic serine aspartate-rich MEPE associated motif (ASARM peptide), could regulate glucose metabolism and insulin signaling [14]. The above findings indicate PHEXmediated association between skeletal function and energy 
metabolism.

Furthermore, phosphate homeostasis, destructed in XLH patients [25], is also connected to energy metabolism [26,27]. Phosphorus contributes to bone development and maintenance [28]. Bone regulates energy metabolism through modifying expression of relative genes such as osteocalcin $(\mathrm{Ocn})$. OCN is produced by osteoblasts and affects beta-cell functions. Overexpression of OCN resulted in aberrant insulin production and sensitivity $[11,29,30]$. All the reports above imply a mineral homeostasis-mediated correlation between mineral homeostasis, bone functions and energy metabolism.

This study presents a series of novel phenotypes in XLH mouse model and provides a new angle of view to study the relationship between skeletal deformities and glucose metabolism. We rescue the abnormal bone and glucose metabolism via modifying mineral homeostasis.

\section{Materials and methods}

\subsection{Mice and diets}

PUG mice were obtained from Model Animal Research Center (MARC) of Nanjing University (Nanjing, Jiangsu, China). All mice were bred in specific pathogen-free (SPF) animal rooms and manipulated according to Animal protocol approved by IACUC of MARC. Mice were housed under a normal $12 \mathrm{~h}$ light/12 h dark with water and food $\mathrm{ad}$ libitum. PUG male mice and their wild-type littermates were divided into three groups, the first was wild-type mice (WT) fed with regular diet (RD, $0.5 \% \mathrm{Pi}$ and $0.5 \% \mathrm{Ca}$ ), the second was PUG fed with RD and the third was PUG fed with high $\mathrm{Pi} / \mathrm{Ca}$ diet (HPD, $2 \% \mathrm{Pi}$ and $1.1 \% \mathrm{Ca}$ ). All three groups were fed with respective diets from ablactation at postnatal 21 days.

\subsection{Body weight and body length measurements}

Body weights of all mice were measured once a week at 5:30 p.m. Whole tail lengths and body lengths were measured after anesthetization by $2.5 \%$ avertin $(5 \mathrm{mg}$ per $10 \mathrm{~g}$ body weight) [31].

\subsection{Bone mineral density (BMD) and X-ray imaging}

Excluding head and tail, lean mass and bone mineral density were assessed by dual-energy X-ray absorptiometry (DEXA) system (PIXImus 2, GE lunar, USA). X-ray photos were taken using Faxitron MS-20 specimen radiography system (Faxitron X-ray Corporation, Wheeling, IL, USA) for $12 \mathrm{~s}$ at $23 \mathrm{kV}$. All mice were fasted overnight $(16 \mathrm{~h})$ and anesthetized by $2.5 \%$ avertin ( $5 \mathrm{mg}$ per $10 \mathrm{~g}$ body weight) before measurements.

\subsection{Blood biochemical analysis}

Blood samples were collected from venous sinus of optical orbit after overnight fasting. Clot blood samples by standing for $2 \mathrm{~h}$ on ice and centrifuge them at 3,000×g for $20 \mathrm{~min}$ at $4^{\circ} \mathrm{C}$ to isolate the serum. Serum was store at $-20^{\circ} \mathrm{C}$ for short period and $-80^{\circ} \mathrm{C}$ for long storage. Serum phosphorus $(\mathrm{Pi})$, calcium $(\mathrm{Ca})$ and alkaline phosphatase (ALP) were detected with the 7600 Clinical Analyzer (Hitachi High-Technologies, Japan).

\subsection{Blood glucose, serum insulin and serum osteocalcin measurements}

Blood glucose levels were tested in blood samples obtained from mice tail tips after fasting from 9:00 a.m. to 5:00 p.m. every week using glucocard blood glucose test meter (GT-1640, ARKRAY Inc, Japan). Mice blood was collected from venous sinus of optical orbit at 9:30 a.m. after fed $\mathrm{ad} \mathrm{lib}$ or fast overnight for serum insulin level detection respectively. Serum insulin and osteocalcin levels were detected via RAT/MOUSE INSULIN ELISA KIT (Millipore, USA) and Mouse Osteocalcin EIA kit (Biomedical Technologies Inc., USA).

\subsection{Glucose tolerance test and insulin tolerance test}

Every two weeks, glucose tolerance test (GTT) or insulin tolerance test (ITT) was carried out after 8 and $6 \mathrm{~h}$ fasting in the daytime respectively. Mice were intraperitoneally injected with D-(+)-glucose (G6152, Sigma, USA; 2 g/kg body weight) for GTT and insulin (Novo Nordisk, Tianjing, China, $0.5 \mathrm{IU} / \mathrm{kg}$ body weight) for ITT. Blood glucose was detected from tail tips at $0,15,30,45,60,90$ and $120 \mathrm{~min}$ after injection.

\subsection{Statistics}

Statistical analyses were determined using unpaired twotailed student's $t$ test. All data are expressed as mean \pm SEM. A $P$-value of less than 0.05 was considered statistically significant. * and $\S, P<0.05$; ** and $\S \S, P<0.01$; *** and $\S \S$, $P<0.001$.

\section{Results}

\subsection{PUG mice show deficient skeletal morphology and} abnormal mineral homeostasis

In different disease models of XLH, for instance, Hyp and Gy mice, they display a series of rickets associated phenotypes, such as growth retardation, skeletal anomalies and mineral deficiency $[2,32]$. PUG mice, with a missense mutation on Phex, were reported as a mouse model of XLH [33]. To confirm the phenotype, we studied the growth sta- 
tus and skeletal development in PUG firstly. Concerning that Phex is located on $\mathrm{X}$ chromosome and female mice displayed randomized $\mathrm{X}$ chromosome inactivation, hemizygous male PUG mice were used for subsequent investigations.

PUG show lower body weight than wild-type mice at the age of weaning (WT: $18.96 \pm 0.24 \mathrm{~g}$; PUG: $15.85 \pm 0.26 \mathrm{~g}$ ) (Figure 1A). Contemporary whole body length was measured (Figure 1B) and PUG displayed shortened skeleton in early growth stage (WT: $7.64 \pm 0.05 \mathrm{~cm}$; PUG: $5.72 \pm 0.06$ $\mathrm{cm})$. Bone mineral density (BMD) was decreased in both local (left femur) (WT: 0.072 $\pm 0.0016 \mathrm{~g} \mathrm{~cm}^{-2}$; PUG: $0.053 \pm 0.0040 \mathrm{~g} \mathrm{~cm}^{-2}$ ) and systemic (WT: $0.057 \pm 0.0007 \mathrm{~g}$ $\mathrm{cm}^{-2}$; PUG: $0.051 \pm 0.0010 \mathrm{~g} \mathrm{~cm}^{-2}$ ) analysis (Figure 1C). X-ray images of PUG lying on its side displayed stunted stature, shorter bone structure and increased curvature of spinal column (Figure 1D).

Furthermore, we measured circulating inorganic phosphorus (Pi), calcium (Ca) and alkaline phosphatase (ALP) levels by analyzing serum of 3-week-old mice. We found out that PUG show decreased Pi levels (WT: 2.44 \pm 0.19 mmol L ${ }^{-1}$; PUG: $2.05 \pm 0.38 \mathrm{mmol} \mathrm{L}^{-1}$ ) (Figure 1E) and increased ALP levels (WT: $385.1 \pm 39.6 \mathrm{mmol} \mathrm{L}^{-1}$; PUG: $826 \pm$
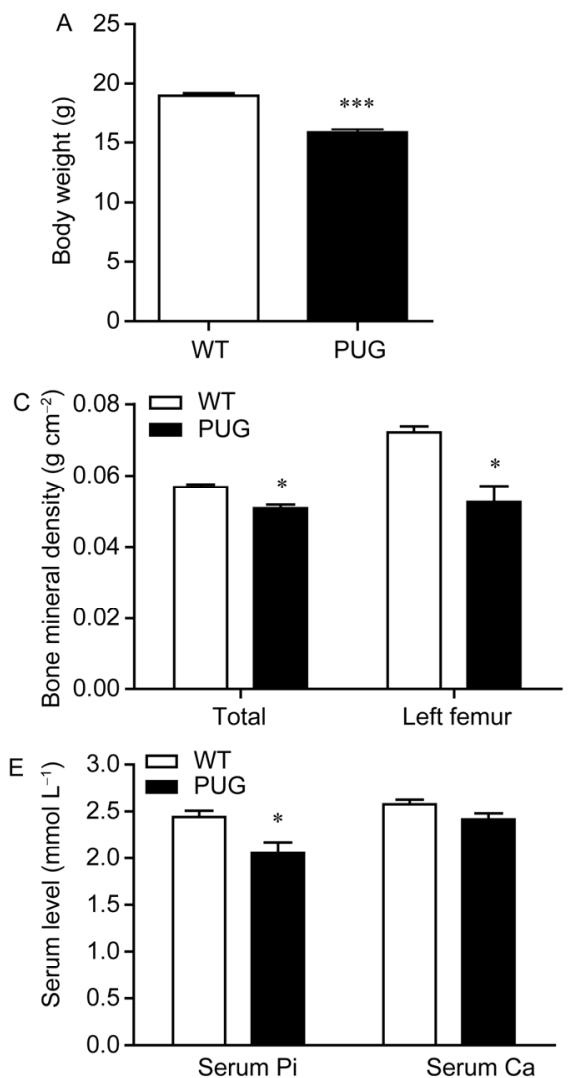

$74.1 \mathrm{mmol} \mathrm{L}^{-1}$ ) (Figure $1 \mathrm{~F}$ ) while $\mathrm{Ca}$ levels remain untouched (WT: $2.56 \pm 0.14 \mathrm{mmol} \mathrm{L}^{-1}$; PUG: $2.42 \pm 0.15 \mathrm{mmol}$ $\mathrm{L}^{-1}$ ) (Figure 1E). All the phenomena above demonstrated that PUG exhibited incipient symptoms of hypophosphatemic rickets which are consistent with XLH patients.

\subsection{PUG mice display affected glucose metabolism}

Previous research implied aberrant glucose metabolism in Phex-deficient mice [22-24], thus we examined blood glucose levels in our model. Three-week-old PUG exhibited significant lower blood glucose levels than wild-type mice after $8 \mathrm{~h}$ fasting (WT: $10.16 \pm 0.22 \mathrm{mmol} \mathrm{L}^{-1}$; PUG: $7.93 \pm 0.45 \mathrm{mmol} \mathrm{L}^{-1}$ ) (Figure 2A), proving imbalanced glucose homeostasis and impaired insulin secretion and function. We tested serum insulin levels in both fed and fasting status at 3 weeks of age. The results showed that there was a notable decline in fed insulin levels (WT: $1.28 \pm 0.82 \mathrm{ng} \mathrm{mL}{ }^{-1}$; PUG: $0.81 \pm 0.44 \mathrm{ng} \mathrm{mL}^{-1}$ ) and a slight drop in fasting insulin levels (WT: $0.45 \pm 0.13 \mathrm{ng} \mathrm{mL}^{-1}$; PUG: $0.37 \pm 0.09 \mathrm{ng} \mathrm{mL} \mathrm{m}^{-1}$ ) (Figure $2 \mathrm{~B}$ ), suggesting disordered glucose metabolism in PUG mice.

To further investigate the scavenging capacity of blood
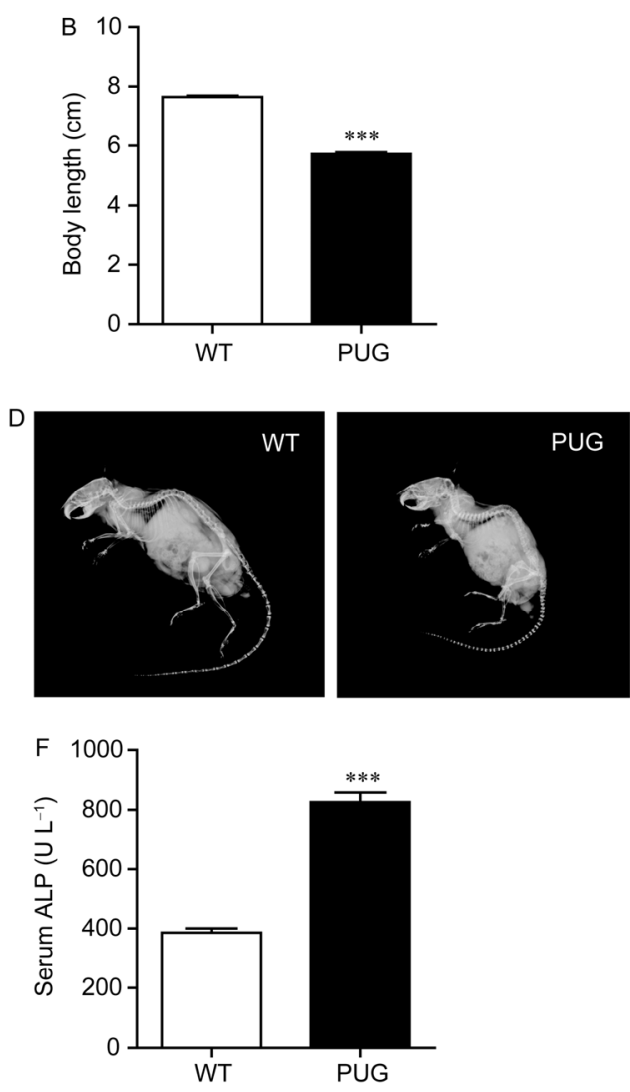

Figure 1 PUG mice show growth retardation, mineral homeostasis abnormity and bone deformities. (A) Whole body weights and (B) whole body lengths of PUG and control mice were measured at 3 weeks of age (PUG, $n=5$; WT, $n=7$ ). C, Both total and left femur BMD of yearling wild-type ( $n=8$ ) and PUG $(n=6)$ mice were measured. D, Bone structures were displayed by whole body X-ray images (sideways) in yearling wild-type and PUG mice. (E) Serum levels of inorganic phosphorus (Pi, WT, $n=7$; PUG, $n=9$ ) and calcium (Ca, WT, $n=7$; PUG, $n=5$ ) and (F) serum alkaline phosphatase (ALP, WT, $n=7$; PUG, $n=5)$ were detected at 3 weeks of age. Data are expressed as mean \pm SEM. *,$P<0.05$; **, $P<0.01 ; * * *, P<0.001$. 

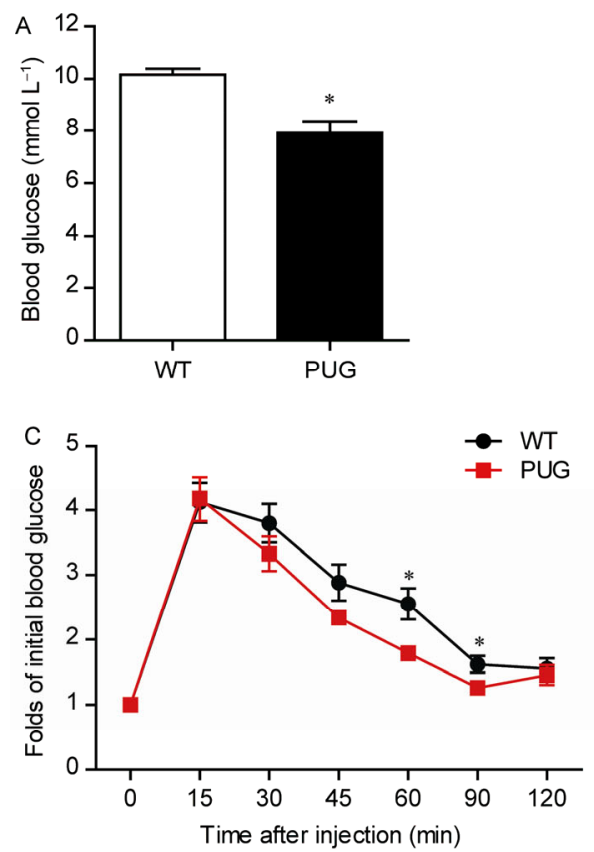
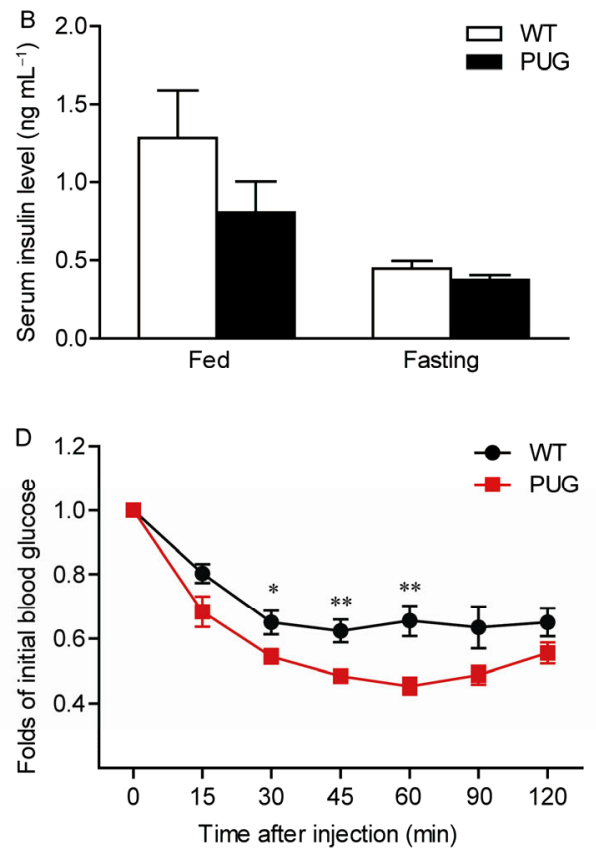

Figure 2 Reduced circulating glucose, insulin levels, improved glucose tolerance and insulin sensitivity in PUG mice. A, After fasting for 8 h from 9:30 a.m. to 5:30 p.m., blood glucose of PUG and WT were detected at postnatal 3rd week ( $n=8$ per group). B, Blood was collected at 9:30 a.m. and serum was isolated for fed status insulin levels detection (WT, $n=7$; PUG, $n=5$ ). Blood was collected at 5:30 p.m. after $8 \mathrm{~h}$ fasting to detect serum insulin levels under fasting status (WT, $n=7$; PUG, $n=9$ ). C, GTT ( $\mathrm{g} \mathrm{kg}^{-1}$ body weight) was performed on 7-week-old WT ( $\left.n=8\right)$ and PUG mice ( $\left.n=6\right)$. D, ITT (0.5 U kg ${ }^{-1}$ body weight) was conducted in 10 -week-old PUG $(n=7)$ and WT mice $(n=8)$. Blood glucose of each point-in-time was compared to that of initial point $(0$ min) and the results are exhibited as proportions in both GTT and ITT. Data are expressed as mean \pm SEM. ${ }^{*}, P<0.05 ; * *, P<0.01$.

glucose and response to insulin, we performed glucose tolerance tests and insulin tolerance tests at 7 and 10 weeks of age, respectively. PUG mice showed significantly improved glu- cose tolerance than control mice (Figure 2C). Moreover, lower blood glucose levels after insulin administration were observed in PUG mice (Figure 2D). These suggested increased ability in disposing of glucose load and enhanced insulin sensitivity in PUG mice. Collectively, blood glucose clearance capacity and peripheral insulin sensitivity were improved in PUG mice compared to even-aged wild-type, suggesting altered glucose metabolism correlative to skeletal disorder.

\subsection{Bone deformity and imbalanced mineral homeo- stasis were partially restored after high $\mathrm{Pi} / \mathrm{Ca}$ diet treatment}

Combined inorganic phosphorus and 1,25- $(\mathrm{OH})_{2} \mathrm{D}_{3}$ are used as therapeutic regimen to treat XLH patients [34,35]. However, animal model research and human cases studies have demonstrated that XLH carriers are resistant to vitamin D therapy [36]. Therefore, we treated 3-week-old PUG with high $\mathrm{Pi} / \mathrm{Ca}$ diet (HPD) containing $2 \%$ inorganic phosphorus and $1.1 \%$ calcium to check whether HPD could rescue retarded growth and defected bone development. Regular diet (RD) with $0.5 \%$ phosphorus and $0.5 \%$ calcium was used as control. Calcium was added to keep the balance between phosphorus and calcium and to avoid skeletal demineraliza- tion and mineral deposits in soft tissues [37,38].

PUG mice were fed with HPD from the age of 3 weeks, with RD fed PUG and WT as controls. Body weights of three groups were measured once a week. After 9 weeks of HPD treatment, PUG gained significant heavier body weight than RD fed PUG (Figure 3A). Osteocalcin (OCN), produced and secreted solely by osteoblasts, is used as a biochemical marker to represent bone formation [39]. Serum OCN level declines as the age increases [40]. Elevation of circulating OCN levels was detected in 3-week-age PUG

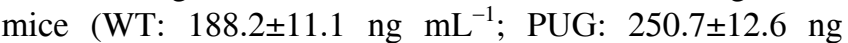
$\mathrm{mL}^{-1}$ ), suggesting disordered skeletal development and altered energy metabolism (Figure 3B). After 5 weeks of treatment, HPD fed PUG displayed corrected serum osteocalcin (WT RD: $49.8 \pm 5.8 \mathrm{ng} \mathrm{mL}^{-1}$; PUG RD: $105.5 \pm 7.5$ ng $\mathrm{mL}^{-1}$; PUG HPD: $56.1 \pm 13.7 \mathrm{ng} \mathrm{mL}^{-1}$ ) (Figure $3 \mathrm{~B}$ ). Wild-type mice showed no difference in serum OCN level before and after HPD treatment (Figure S1 in Supporting Information). After applying one year of high $\mathrm{Pi} / \mathrm{Ca}$ diet, PUG acquired improved body length (WT RD: $9.54 \pm 0.06$ cm; PUG RD: $7.85 \pm 0.15 \mathrm{~cm}$; PUG HPD: $8.83 \pm 0.11 \mathrm{~cm}$ ) (Figure 3C). In addition, bone mineral density and lean mass displayed notable raise (Figure 3D and E). Circulating inorganic phosphorus (Figure $3 \mathrm{~F}$ ) and alkaline phosphatase (Figure 3G) were rescued after 2 weeks of HPD treatment and kept close to normal levels after long period treatment. These results show that skeletal deformity was rescued after restored mineral homeostasis through phosphorus and calcium supplementation. 

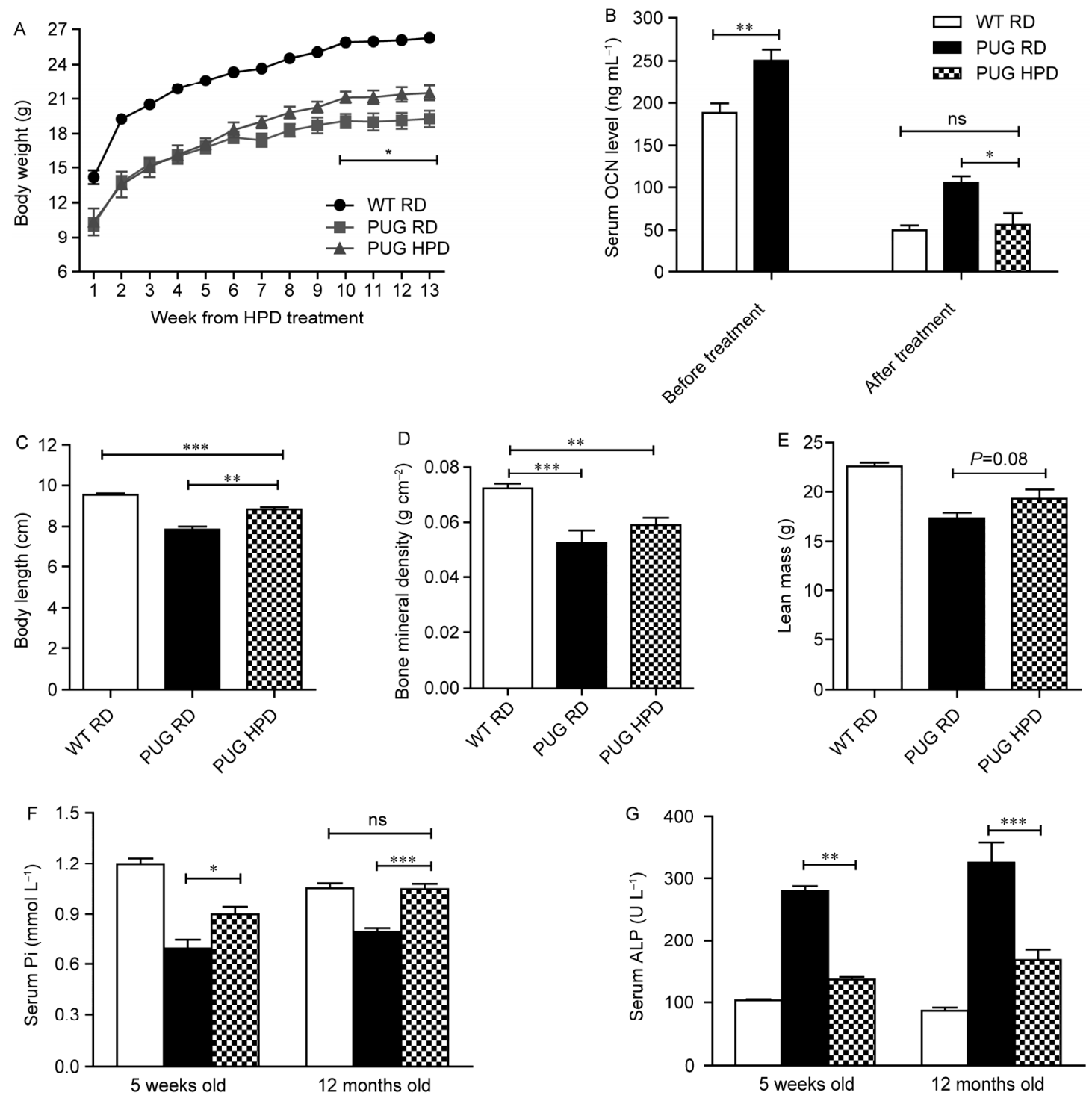

Figure $3 \mathrm{Pi}$ and Ca supplements partially rescued growth retardation and mineral deficiency of PUG mice. PUG mice were divided into two groups and were fed with regular diet (RD) and high Pi/Ca diet (HPD) respectively. Wild-type mice were fed with RD as control. A, Body weights of WT ( $n=8$ ), RD fed PUG $(n=7)$ and HPD fed PUG mice $(n=6)$ were measured once a week during HPD treatment. B, 3-week-old RD fed WT $(n=7)$ and PUG $(n=5)$ were used to detect total OCN levels. Six pairs of WT and PUG mice were fed with HPD. RD fed wild-type mice $(n=7)$ were used as control. After 5 weeks of Pi and Ca supplementation, total osteocalcin (OCN) levels were detected. (C) Whole body length, (D) bone mineral density of left femur and (E) lean mass were detected in yearling WT $(n=8)$, RD PUG $(n=6)$ and HPD PUG mice $(n=4)$. Blood biochemistry tests were conducted by testing mouse serum to detect circulating (F) inorganic phosphorus (Pi) and (G) alkaline phosphatase (ALP) levels at 5 weeks of age (WT, $n=8$; RD PUG, $n=8$; HPD PUG, $n=6$ ) and 1 -year-old (WT, $n=8$; RD PUG, $n=6$; HPD PUG, $n=6$ ). Data are expressed as mean \pm SEM. *, $P<0.05$; **, $P<0.01$; ***, $P<0.001$.

\subsection{Rescued glucose metabolism in high $\mathrm{Pi} / \mathrm{Ca}$ diet treated PUG mice}

We have described affected glucose metabolism in PUG mice and demonstrated that mineral supplements prevent growth retardation and bone deformity. We inquired about whether the altered glucose homeostasis was engendered by hypophosphatemia, so we examined fasting insulin levels in HPD fed PUG mice. As shown in Figure 4A, serum insulin levels returned to normal levels (WT RD: $0.54 \pm 0.06 \mathrm{ng}$ $\mathrm{mL}^{-1}$; PUG RD: $0.39 \pm 0.08 \mathrm{ng} \mathrm{mL}^{-1}$; PUG HPD: $0.53 \pm 0.07$ $\mathrm{ng} \mathrm{mL} \mathrm{m}^{-1}$ ) after 5 weeks of treatment. We performed GTT and ITT 2 weeks later. It shows that PUG obtained normalized peripheral insulin sensitivity (Figure 4B) after feeding HPD for 7 weeks. Simultaneously, glucose clearance capacity was restored (Figure 4C). The area under curve of GTT represented approximate glucose tolerance ability between PUG and wild-type mice (WT RD: 253.6 \pm 14.6 ; PUG RD: 207.6 \pm 12.7 ; PUG HPD: 239.0 \pm 13.6 ) (Figure 4D). The above findings together demonstrated that glucose metabolism was rescued after phosphorus and calcium supplementation and suggested that mineral homeostasis affects glucose homeostasis in skeletal disorder. 

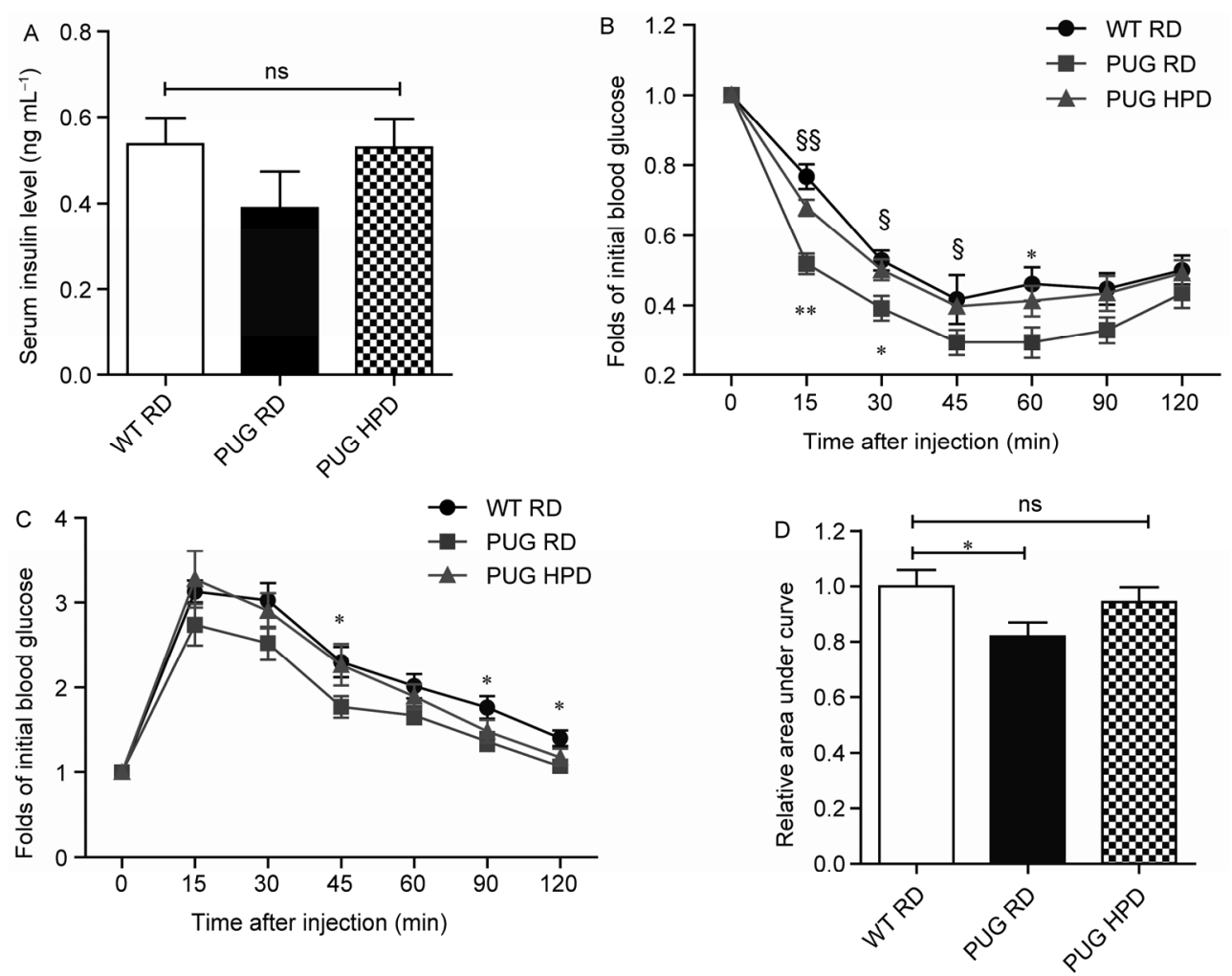

Figure 4 High Pi/Ca diet treated PUG mice show improved insulin production, normalized insulin sensitivity and glucose metabolism. A, Serum insulin levels were detected in RD PUG ( $n=7)$, HPD PUG $(n=6)$ and control RD WT mice $(n=8)$ after 5 weeks of HPD treatment. B, Insulin sensitivity was tested by ITT ( $0.5 \mathrm{U} \mathrm{kg}^{-1}$ body weight) after 7 weeks of treatment. C, Glucose metabolism was detected at the same time (WT, $n=8$; RD PUG, $n=7$; HPD PUG, $n=4$ ) by GTT ( $2 \mathrm{~g} \mathrm{~kg}^{-1}$ body weight). Blood glucose was compared to initial point $(0 \mathrm{~min})$ and the results are demonstrated as proportions in both GTT and ITT. Area under curve of GTT (D) was calculated. Data are expressed as mean \pm SEM. ns stands for $P>0.05$. * stands for $P<0.05$ and $* *$ stands for $P<0.01$ when RD PUG was compared with WT. § stands for $P<0.05$ and $\S$ stands for $P<0.01$ when RD PUG was compared with HPD PUG.

\section{Discussion}

Regulation of energy metabolism by bone has long been discussed. In this study, phex mutation induced not only defected bone development but also altered glucose metabolism. We described enhanced glucose tolerance and insulin sensitivity associated with bone deformities and disordered mineral metabolism for the first time in animal model of XLH. In addition, we rescued both skeletal and metabolic abnormalities via restoring mineral homeostasis, suggesting a close correlation between bone and energy metabolism. Normalized glucose cleaning capability and peripheral insulin sensitivity, following restored serum phosphorus level, demonstrate that mineral homeostasis plays an important role in regulation of glucose metabolism by bone.

We also discovered decreased blood glucose in XLH mouse model. Blood glucose is regulated by G6Pase in the liver. Elevated hepatic G6Pase activity brings about enhanced glyconeogenesis and glycogenolysis, leading to serum glucose elevation [41]. However, another study reported that glucose-6-phosphatase (G6Pase) activity was increased in both XLH mouse model and phosphate-deprived mice [42]. We did not measure G6Pase activity in PUG mice. If hepatic G6Pase activity was upregulated, we spec- ulated the reason might be a feedback effect aiming to reverse the abnormal glucose metabolism according to published reports [43]. Moreover, blood glucose homeostasis could be regulated by other different signaling. Several studies show that blood glucose could be modulated by intestine G6PC activity [44], glucose transportation [43] and glucose uptake [45], resulting in irrelevance between plasma glucose level and hepatic G6Pase activity. In XLH mouse model, decreased renal glucose reabsorption activity is also considered contributory to the decreased blood glucose [22]. Otherwise the reduced blood glucose of PUG mice resulted from abnormal glucose transport and oxidation stimulated by OCN [45].

Osteocalcin (OCN), which is secreted by the bone, is one of the mediators communicating with adipose $[46,47]$. OCN is also used as a biomarker of skeletal development, and increased serum OCN level is associated with increased bone mineral density during osteoporosis treatment $[48,49]$. However, in our study, elevated OCN levels were accompanied by decreased BMD. This result might be attributed to retarded growth and deficient glucose metabolism [50,51]. Several researches declare that BMD and osteocalcin level can be influenced by estrogen, calcium and fat mass, resulting in decreased BMD and increased osteocalcin level 
$[52,53]$. It may explain the contradiction between BMD decline and serum OCN level elevation in PUG mice.

OCN is also involved in glucose metabolism via increasing adiponectin in mice [54]. Importantly, uncarboxylated form of OCN promotes insulin secretion to affect glucose metabolism by means of stimulating glucagons-like peptide-1 (GLP-1) [55]. OCN circulation can be attenuated by dietary phosphorus supplementation [56], implying functions of phosphorus in regulating OCN secretion and function. Of note, our work revealed restored OCN levels and insulin levels after mineral homeostasis recovery in PUG mice, followed by restored glucose tolerance and insulin sensitivity. Overall, there may be a mechanism in which aberrant phosphate homeostasis aroused by bone dysfunction regulates glucose metabolism through regulating circulating OCN level.

Bone is regulated by adipose-secreted leptin which acts on the osteoblast endocrine cell to inhibit bone formation through hypothalamic and sympathetic nervous system relays [57-60]. On the other hand, OCN secretion is facilitated by bone to regulate adiposity, glucose metabolism, and insulin sensitivity in turn [61-63]. Ocn-deficient mice exert not only mildly increased bone mass but also lessened $\beta$-cell proliferation, glucose intolerance and insulin resistant phenotypes, imitating type II diabetes [29,64]. Correlations between circulating OCN levels and $\beta$-cell functions or glucose metabolism were observed in obese adults and type II diabetes patients [65,66], suggesting secretion role of skeleton in regulating lipid anabolism and catabolism. Adiponectin secretion was accelerated by OCN [45] while serum $\mathrm{OCN}$ level was positively correlated with adiponectin receptor 1 (AdipoRl) expression [67], developing a feedback loop between osseous tissue and energy metabolism $[68,69]$. Therefore, OCN elevation in XLH disease is probable to exhibit damaged lipid metabolism. It highlights new arenas for potential investigation in skeletal regulation of energy metabolism.

In summary, our findings represent significant progress in understanding the mechanism that bone affects energy metabolism through regulating mineral homeostasis. OCN could be a potential target for rickets and metabolic diseases treatment in the future. Though more efforts should be made to identify how OCN functions as a mediator between PHEX and mineral homeostasis. Additionally, further exploration is needed to clarify how Phex mutation brings about imbalanced phosphorus homeostasis.

We thank Lin ZhaoYu (Model Animal Research Center, Nanjing University) for the revision of this manuscript. These studies were supported by National Key Technology Support Program (2011BAI15B02, 2012BAI39B01) and National Key Basic Research Program of China (2011CB944104).

1 Jap TS, Chiu CY, Niu DM, Levine MA. Three novel mutations in the PHEX gene in Chinese subjects with hypophosphatemic rickets extends genotypic variability. Calcif Tissue Int, 2011, 88: 370-377
2 Tenenhouse HS. X-linked hypophosphataemia: a homologous disorder in humans and mice. Nephrol Dial Transplant, 1999, 14: 333-341

3 Drezner MK. PHEX gene and hypophosphatemia. Kidney Int, 2000, 57: $9-18$

4 Ichikawa S, Traxler EA, Estwick SA, Curry LR, Johnson ML, Sorenson AH, Imel EA, Econs MJ. Mutational survey of the PHEX gene in patients with X-linked hypophosphatemic rickets. Bone, 2008, 43: 663-666

5 Baroncelli GI, Bertelloni S, Sodini F, Galli L, Vanacore T, Fiore L, Saggese G. Genetic advances, biochemical and clinical features and critical approach to treatment of patients with X-linked hypophosphatemic rickets. Pediatr Endocrinol Rev, 2004, 1: 361-379

6 Du L, Desbarats M, Viel J, Glorieux FH, Cawthorn C, Ecarot B. cDNA cloning of the murine Pex gene implicated in X-linked hypophosphatemia and evidence for expression in bone. Genomics, 1996, 36: 22-28

7 Fukumoto S, Martin TJ. Bone as an endocrine organ. Trends Endocrinol Metab, 2009, 20: 230-236

8 Vervloet MG, Massy ZA, Brandenburg VM, Mazzaferro S, Cozzolino M, Urena-Torres P, Bover J, Goldsmith D. Bone: a new endocrine organ at the heart of chronic kidney disease and mineral and bone disorders. Lancet Diabetes Endocrinol, 2014, 2: 427-436

9 Chen X, Tian HM, Pei FX, Yu XJ. Bone functions as a novel endocrine organ in energy metabolism. Chin Med J, 2012, 125: 4117-4121

10 Garcia-Martin A, Reyes-Garcia R, Avila-Rubio V, Munoz-Torres M. Osteocalcin: a link between bone homeostasis and energy metabolism. Endocrinol Nutr, 2013, 60: 260-263

11 Pi M, Quarles LD. Novel bone endocrine networks integrating mineral and energy metabolism. Curr Osteop Rep, 2013, 11: 391-399

12 Yuan B, Takaiwa M, Clemens TL, Feng JQ, Kumar R, Rowe PS, Xie $\mathrm{Y}$, Drezner MK. Aberrant Phex function in osteoblasts and osteocytes alone underlies murine X-linked hypophosphatemia. J Clin Invest, 2008, 118: 722-734

13 Salmon B, Bardet C, Khaddam M, Naji J, Coyac BR, Baroukh B, Letourneur F, Lesieur J, Decup F, Le Denmat D, Nicoletti A, Poliard A, Rowe PS, Huet E, Vital SO, Linglart A, McKee MD, Chaussain C. MEPE-derived ASARM peptide inhibits odontogenic differentiation of dental pulp stem cells and impairs mineralization in tooth models of X-linked hypophosphatemia. PLoS One, 2013, 8: e56749

14 Rowe PS. Regulation of bone-renal mineral and energy metabolism: the PHEX, FGF23, DMP1, MEPE ASARM pathway. Crit Rev Eukaryot Gene Exp, 2012, 22: 61-86

15 Roetzer KM, Varga F, Zwettler E, Nawrot-Wawrzyniak K, Haller J, Forster E, Klaushofer K. Novel PHEX mutation associated with hypophosphatemic rickets. Nephron Physiol, 2007, 106: 8-12

16 Cheung M, Roschger P, Klaushofer K, Veilleux LN, Roughley P, Glorieux FH, Rauch F. Cortical and trabecular bone density in X-linked hypophosphatemic rickets. J Clin Endocrinol Metab, 2013, 98: E954-961

17 Uchihashi K, Nakatani T, Goetz R, Mohammadi M, He X, Razzaque MS. FGF23-induced hypophosphatemia persists in Hyp mice deficient in the WNT coreceptor Lrp6. Contrib Nephrol, 2013, 180: 124-137

18 Sun X, Zemel MB. 1Alpha,25-dihydroxyvitamin D3 modulation of adipocyte reactive oxygen species production. Obesity (Silver Spring), 2007, 15: 1944-1953

19 Wong KE, Szeto FL, Zhang W, Ye H, Kong J, Zhang Z, Sun XJ, Li $\mathrm{YC}$. Involvement of the vitamin D receptor in energy metabolism: regulation of uncoupling proteins. Am J Physiol Endocrinol Metab, 2009, 296: E820-828

20 Wang WL, Welsh J, Tenniswood M. 1,25-Dihydroxyvitamin D3 modulates lipid metabolism in prostate cancer cells through miRNA mediated regulation of PPARA. J Steroid Biochem Mol Biol, 2013, 136: 247-251

21 Mirza MA, Alsio J, Hammarstedt A, Erben RG, Michaelsson K, Tivesten A, Marsell R, Orwoll E, Karlsson MK, Ljunggren O, Mellstrom D, Lind L, Ohlsson C, Larsson TE. Circulating fibroblast 
growth factor-23 is associated with fat mass and dyslipidemia in two independent cohorts of elderly individuals. Arterioscler Thromb Vasc Biol, 2011, 31: 219-227

22 Muhlbauer RC, Fleisch H. Abnormal renal glucose handling in X-linked hypophosphataemic mice. Clin Sci (Lond), 1991, 80: 71-76

23 Capparelli AW, Roh D, Dhiman JK, Jo OD, Yanagawa N. Altered proximal tubule glucose metabolism in X-linked hypophosphatemic mice. Endocrinology, 1992, 130: 328-334

24 Rifas L, Gupta A, Hruska KA, Avioli LV. Altered osteoblast gluconeogenesis in $\mathrm{X}$-linked hypophosphatemic mice is associated with a depressed intracellular pH. Calcif Tissue Int, 1995, 57: 60-63

25 Feng JQ, Clinkenbeard EL, Yuan B, White KE, Drezner MK. Osteocyte regulation of phosphate homeostasis and bone mineralization underlies the pathophysiology of the heritable disorders of rickets and osteomalacia. Bone, 2013, 54: 213-221

26 Confavreux CB. Bone: from a reservoir of minerals to a regulator of energy metabolism. Kidney Int Suppl, 2011, 121: S14-19

27 Addison WN, Masica DL, Gray JJ, McKee MD. Phosphorylationdependent inhibition of mineralization by osteopontin ASARM peptides is regulated by PHEX cleavage. J Bone Miner Res, 2010, 25 : 695-705

28 Jones G. Early life nutrition and bone development in children. Nestle Nutr Workshop Ser Pediatr Program, 2011, 68: 227-233; discussion 233-226

29 Lee NK, Sowa H, Hinoi E, Ferron M, Ahn JD, Confavreux C, Dacquin R, Mee PJ, McKee MD, Jung DY, Zhang Z, Kim JK, Mauvais-Jarvis F, Ducy P, Karsenty G. Endocrine regulation of energy metabolism by the skeleton. Cell, 2007, 130: 456-469

30 Neve A, Corrado A, Cantatore FP. Osteocalcin: skeletal and extra-skeletal effects. J Cell Physiol, 2013, 228: 1149-1153

31 Bourne W. The present status of avertin in anaesthesia. Can Med Assoc J, 1932, 27: 515-516

32 Seitz S, Rendenbach C, Barvencik F, Streichert T, Jeschke A, Schulze J, Amling M, Schinke T. Retinol deprivation partially rescues the skeletal mineralization defects of Phex-deficient Hyp mice. Bone, 2013, 53: 231-238

33 Xiong X, Qi X, Ge X, Gu P, Zhao J, Zhao Q, Gao X. A novel Phex mutation with defective glycosylation causes hypophosphatemia and rickets in mice. J Biomed Sci, 2008, 15: 47-59

34 Linglart A, Biosse-Duplan M, Briot K, Chaussain C, Esterle L, Guillaume-Czitrom S, Kamenicky P, Nevoux J, Prie D, Rothenbuhler A, Wicart P, Harvengt P. Therapeutic management of hypophosphatemic rickets from infancy to adulthood. Endocr Connect, 2014, 3: R13-30

35 Quinlan C, Guegan K, Offiah A, Neill RO, Hiorns MP, Ellard S, Bockenhauer D, Hoff WV, Waters AM. Growth in PHEX-associated $\mathrm{X}$-linked hypophosphatemic rickets: the importance of early treatment. Pediatr Nephrol, 2012, 27: 581-588

36 Aono Y, Yamazaki Y, Yasutake J, Kawata T, Hasegawa H, Urakawa I, Fujita T, Wada M, Yamashita T, Fukumoto S, Shimada T. Therapeutic effects of anti-FGF23 antibodies in hypophosphatemic rickets/osteomalacia. J Bone Miner Res, 2009, 24: 1879-1888

37 Civitelli R, Ziambaras K. Calcium and phosphate homeostasis: concerted interplay of new regulators. J Endocrinol Invest, 2011, 34: 3-7

38 Begot L, Collombet JM, Renault S, Butigieg X, Andre C, Zerath E, Holy X. Effects of high-phosphorus and/or low-calcium diets on bone tissue in trained male rats. Med Sci Sports Exerc, 2011, 43: 54-63

39 Aoki A, Muneyuki T, Yoshida M, Munakata H, Ishikawa SE, Sugawara H, Kawakami M, Kakei M. Circulating osteocalcin is increased in early-stage diabetes. Diabetes Res Clin Pract, 2011, 92: 181-186

40 Li X, Srivastava AK, Gu W, Masinde G, Mohan S, Baylink DJ. Opposing changes in osteocalcin levels in bone vs serum during the acquisition of peak bone density in $\mathrm{C} 3 \mathrm{H} / \mathrm{HeJ}$ and $\mathrm{C} 57 \mathrm{BL} / 6 \mathrm{~J}$ mice. Calcif Tissue Int, 2002, 71: 416-420

41 Garcia-Caraballo SC, Comhair TM, Verheyen F, Gaemers I, Schaap FG, Houten SM, Hakvoort TB, Dejong CH, Lamers WH, Koehler SE. Prevention and reversal of hepatic steatosis with a high-protein diet in mice. Biochim Biophys Acta, 2013, 1832: 685-695

42 Xie W, Mechin MC, Dubois SG, Lajeunesse D, van de Werve G. Upregulation of liver glucose-6-phosphatase in X-linked hypophosphatemic mice. Horm Metab Res, 2002, 34: 288-292

43 Berglund ED, Li CY, Ayala JE, McGuinness OP, Wasserman DH. Regulation of endogenous glucose production in glucose transporter 4 over-expressing mice. PLoS One, 2012, 7: e52355

44 Troy S, Soty M, Ribeiro L, Laval L, Migrenne S, Fioramonti X, Pillot B, Fauveau V, Aubert R, Viollet B, Foretz M, Leclerc J, Duchampt A, Zitoun C, Thorens B, Magnan C, Mithieux G, Andreelli F. Intestinal gluconeogenesis is a key factor for early metabolic changes after gastric bypass but not after gastric lap-band in mice. Cell metabolism, 2008, 8: 201-211

45 Hill HS, Grams J, Walton RG, Liu J, Moellering DR, Garvey WT. Carboxylated and uncarboxylated forms of osteocalcin directly modulate the glucose transport system and inflammation in adipocytes. Horm Metab Res, 2014, 46: 341-347

46 Labouesse MA, Gertz ER, Piccolo BD, Souza EC, Schuster GU, Witbracht MG, Woodhouse LR, Adams SH, Keim NL, Van Loan MD. Associations among endocrine, inflammatory, and bone markers, body composition and weight loss induced bone loss. Bone, 2014, 64C: $138-146$

47 Wei J, Ferron M, Clarke CJ, Hannun YA, Jiang H, Blaner WS, Karsenty G. Bone-specific insulin resistance disrupts whole-body glucose homeostasis via decreased osteocalcin activation. J Clin Invest, 2014, 124: 1-13

48 Zhai YK, Pan YL, Niu YB, Li CR, Wu XL, Fan WT, Lu TL, Mei QB, Xian CJ. The importance of the prenyl group in the activities of osthole in enhancing bone formation and inhibiting bone resorption in vitro. Int J Endocrinol, 2014, 2014: 921954

49 Petrova NL, Dew TK, Musto RL, Sherwood RA, Bates M, Moniz CF, Edmonds ME. Inflammatory and bone turnover markers in a crosssectional and prospective study of acute Charcot osteoarthropathy. Diabetic Med, 2015, 32: 267-273

50 Sheng L, Cao W, Cha B, Chen Z, Wang F, Liu J. Serum osteocalcin level and its association with carotid atherosclerosis in patients with type 2 diabetes. Cardiovasc Diabetol, 2013, 12: 22

51 Yamaguchi T, Sugimoto T. Bone metabolism and fracture risk in type 2 diabetes mellitus. Bonekey Rep, 2012, 1: 36

52 Gao X, Ma W, Dong H, Yong Z, Su R. Establishing a rapid animal model of osteoporosis with ovariectomy plus low calcium diet in rats. Int J Clin Exp Pathol, 2014, 7: 5123-5128

53 Cawley NX, Yanik T, Woronowicz A, Chang W, Marini JC, Loh YP. Obese carboxypeptidase E knockout mice exhibit multiple defects in peptide hormone processing contributing to low bone mineral density. Am J Physiol Endocrinol Metab, 2010, 299: E189-197

54 Buday B, Pach FP, Literati-Nagy B, Vitai M, Vecsei Z, Koranyi L. Serum osteocalcin is associated with improved metabolic state via adiponectin in females versus testosterone in males. Gender specific nature of the bone-energy homeostasis axis. Bone, 2013, 57: 98-104

55 Mizokami A, Yasutake Y, Gao J, Matsuda M, Takahashi I, Takeuchi H, Hirata M. Osteocalcin induces release of glucagon-like peptide-1 and thereby stimulates insulin secretion in mice. PLoS One, 2013, 8: e57375

56 Tsuji H, Cawthorn C, Ecarot B. Abnormal modulation of serum osteocalcin by dietary phosphate and 1,25-dihydroxyvitamin D3 in the hypophosphatemic mouse. J Bone Miner Res, 1996, 11: 1234-1240

57 Motyl KJ, Rosen CJ. Understanding leptin-dependent regulation of skeletal homeostasis. Biochimie, 2012, 94: 2089-2096

58 Cirmanova V, Bayer M, Starka L, Zajickova K. The effect of leptin on bone: an evolving concept of action. Physiol Res, 2008, 57: S143-151

59 Karsenty G. Convergence between bone and energy homeostases: leptin regulation of bone mass. Cell Metab, 2006, 4: 341-348

60 Pogoda P, Egermann M, Schnell JC, Priemel M, Schilling AF, Alini M, Schinke T, Rueger JM, Schneider E, Clarke I, Amling M. Leptin inhibits bone formation not only in rodents, but also in sheep. J Bone 
Miner Res, 2006, 21: 1591-1599

61 Amelio PD, Panico A, Spertino E, Isaia GC. Energy metabolism and the skeleton: reciprocal interplay. World J Orthop, 2012, 3: 190-198

62 Garcia-Martin A, Reyes-Garcia R, Avila-Rubio V, Munoz-Torres M. Osteocalcin: a link between bone homeostasis and energy metabolism. Endocrinol Nutr, 2013, 60: 260-263

63 Rochefort GY, Rocher E, Aveline PC, Garnero P, Bab I, Chappard C, Jaffre C, Benhamou CL. Osteocalcin-insulin relationship in obese children: a role for the skeleton in energy metabolism. Clin Endocrinol (Oxf), 2011, 75: 265-270

64 Ducy P, Desbois C, Boyce B, Pinero G, Story B, Dunstan C, Smith E, Bonadio J, Goldstein S, Gundberg C, Bradley A, Karsenty G. Increased bone formation in osteocalcin-deficient mice. Nature, 1996, 382: 448-452

65 Gower BA, Pollock NK, Casazza K, Clemens TL, Goree LL, Granger WM. Associations of total and undercarboxylated osteocalcin with peripheral and hepatic insulin sensitivity and beta-cell function in overweight adults. J Clin Endocrinol Metab, 2013, 98: E1173-1180

66 Rui X, Xu B, Su J, Pan C, Zhan C, Su B, Li H, Wang J, Sheng H, Qu S. Differential pattern for regulating insulin secretion, insulin resistance, and lipid metabolism by osteocalcin in male and female T2DM patients. Med Sci Monit, 2014, 20: 711-719

67 Lin YY, Chen CY, Chuang TY, Lin Y, Liu HY, Mersmann HJ, Wu SC, Ding ST. Adiponectin receptor 1 regulates bone formation and osteoblast differentiation by GSK-3beta/beta-Catenin signaling in mice. Bone, 2014, 64C: 147-154

68 Confavreux CB, Levine RL, Karsenty G. A paradigm of integrative physiology, the crosstalk between bone and energy metabolisms. Mol Cell Endocrinol, 2009, 310: 21-29

69 Motyl KJ, McCabe LR, Schwartz AV. Bone and glucose metabolism: a two-way street. Arch Biochem Biophys, 2010, 503: 2-10

Open Access This article is distributed under the terms of the Creative Commons Attribution License which permits any use, distribution, and reproduction in any medium, provided the original author(s) and source are credited.

\section{Supporting Information}

Figure S1 Serum osteocalcin levels of wild-type mice were untouched after high Pi/Ca diet treatment. Serum of RD WT ( $n=7)$ and HPD WT ( $n=14$ ) was collected and isolated after 5 weeks of phosphorus and calcium supplementation. Total OCN levels were detected. Data are expressed as mean \pm SEM. ns stands for $P>0.05$.

The supporting information is available online at life.scichina.com and link.springer.com. The supporting materials are published as submitted, without typesetting or editing. The responsibility for scientific accuracy and content remains entirely with the authors. 